\title{
Benzothiazines in Synthesis. A Formal Total Synthesis of Pseudopteroxazole
}

\author{
Michael Harmata ${ }^{*}$, Zhengxin Cai, and Yugang Chen \\ Department of Chemistry, University of Missouri-Columbia, Columbia, Missouri 65211
}

\begin{abstract}

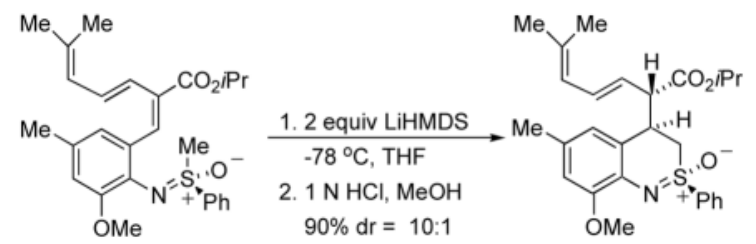

A formal total synthesis of the antitubercular natural product was accomplished. This work was undertaken to address certain stereochemical problems in our initial synthesis. By using an ester group as a surrogate for a methyl group, we were able to intercept a key intermediate in our first synthesis with better selectivity and greater convergence than had previously been the case.
\end{abstract}

\section{Introduction}

The problem of tuberculosis has accompanied mankind for millennia. ${ }^{1}$ At present, approximately one third of the world's population is infected with the causative organism, Mycobacterium tuberculosis. Of this group, 5-10\% proceed to active disease. Over two million people a year die worldwide due to tuberculosis.

Though still a disease that can be treated, tuberculosis often requires chemotherapy on the order of months or years to achieve a cure. This long course often results in non-compliance on the part of patients and this has led to the emergence of moderately drug resistant (MDR) and extensively drug resistant (XDR) strains of the disease. The latter are resistant to the typical first line of drugs used for the treatment of TB as well as at least two drugs comprising the second line of defense

The persistence of this disease and in particular the rise of exceptionally resistant strains of the TB microorganism have made the discovery of new chemotherapies a priority. As is often the case, natural products can provide lead compounds for the development of new drugs, and a number of natural products with antitubercular properties have been identified. ${ }^{2}$

One such compound is pseudopteroxazole (1), which was isolated from the sea whip Pseudopterogorgia elisabethae by Rodriguez and co-workers. ${ }^{3}$ This compound displayed significant activity against $M$. tuberculosis $\mathrm{H} 37 \mathrm{Rv}$ and thus is a potential lead for the development of antitubercular agents. Corey corrected the stereochemical assignment originally given to 1 and also produced the first total synthesis of the compound. ${ }^{4}$ We published a synthesis of $\mathbf{1}$ as well, ${ }^{5}$ further demonstrating the synthetic utility of enantiomerically pure benzothiazines in synthesis. 


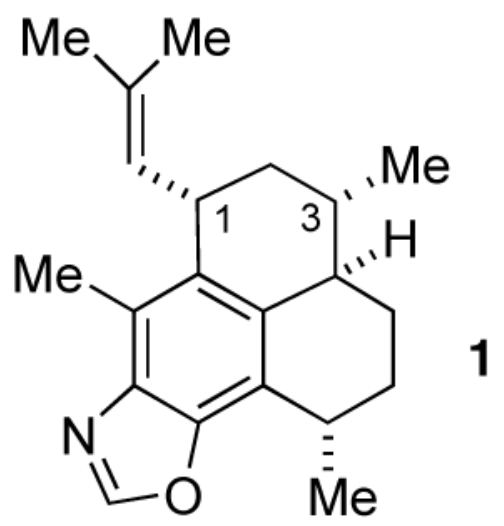

However, our first synthesis was not without some problems. A key step involved the intramolecular conjugate addition of the sulfoximine carbanion derived from $\mathbf{2}$ to afford $\mathbf{3}$ (Scheme 1). This proceeded in high yield and diastereoselectivity. Unfortunately, the diastereoselection was in a direction opposite to that desired and ultimately the stereochemistry at the methyl-bearing carbon atom, the one that would be carbon 3 of pseudopteroxazole, had to be corrected. Once this was done, the synthesis of diene $\mathbf{4}$ proved to be straightforward, as did the conversion of the latter to pseudopteroxazole. We thus set out to prepare 4 via a modified route, and this report details the results of our efforts.

\section{Results and Discussion}

Our plan was to bring in all of the elements needed to construct $\mathbf{4}$ at a very early stage of the synthesis and use the inherent diastereoselectivity of the benzothiazine formation to our advantage. First, we made phosphonate $\mathbf{8}$ from commercially available 3-methyl-2-butenal $\mathbf{5}$ and trimethyl phosphonoacetate 6 in 4 steps (Scheme 2). ${ }^{6}$ This reagent was then coupled with 2-bromo-3-methoxy-5-methylbenzaldehyde $\mathbf{9}^{7}$ to give $\mathbf{1 0}$ with high stereoselectivity using Ba $(\mathrm{OH}) 2$ as base (Scheme 3). ${ }^{8}$

A key step was the Buchwald-Hartwig coupling of triene $\mathbf{1 0}$ with sulfoximine $(R)-\mathbf{1 1} .{ }^{9} \mathrm{We}$ were pleased to find that the coupling product 12 could be obtained in $81 \%$ yield, with minimal complications due to Heck reactions, a side reaction that we feared might dash our hopes of using this strategy. ${ }^{10}$

The next critical step was the intramolecular Michael addition. ${ }^{11}$ Treatment of 12 with LiHMDS followed by quenching with $\mathrm{HCl}$ in cold methanol afforded $\mathbf{1 3}$ with a diastereoselectivity that was as high as 10:1. ${ }^{12}$ The stereochemical outcome of the reaction could be rationalized on the basis of a model we presented earlier ${ }^{4}$ and, in fact, was the same stereochemical outcome observed for the formation of $\mathbf{3}$. However, the key difference is that we planned to convert the ester group in $\mathbf{1 3}$ to a methyl group en route to $\mathbf{4}$.

Thus, treatment of 13 with DIBAL afforded the corresponding alcohol 14 in $88 \%$ yield. Mesylation afforded the corresponding mesylate 15. Attempted reduction of this mesylate with various reducing agents did not proceed very successfully. After numerous attempts at reduction of this and related sulfonates, we ultimately used a procedure that presumably resulted in the in situ formation of the corresponding iodide with concomitant reduction. Thus, treatment of $\mathbf{1 5}$ with excess lithium iodide and excess lithium triethylborohydride at $-30{ }^{\circ} \mathrm{C}$ for $26 \mathrm{~h}$ resulted in the formation of $\mathbf{4}$ in $79 \%$ yield, thereby completing a formal total synthesis of 1. 


\section{Conclusion}

This approach to 4 required 6 steps from aldehyde 9 (conversion of $\mathbf{1 2}$ to $\mathbf{1 3}$ shows the workup as step 2). The old procedure (Scheme 1) required 7 steps from the same aldehyde, but suffered from the need to separate a significant amount of undesired stereoisomer en route to the synthesis of 4. Further, in this new approach, we have demonstrated that the palladiumcatalyzed coupling of a sulfoximine to a highly unsaturated compound is possible in high yield, without loss of material due to other palladium-catalyzed processes. The reaction time for the coupling is significantly shorter than what has been typically reported and only a slight excess of $\mathbf{1 1}$ was needed to produce a very high yield of $\mathbf{1 2}$.

This work further establishes that benzothiazines are easily prepared templates that are useful for total synthesis. Further studies of their synthesis and applications will be reported in due course.

\section{Experimental Section}

(2E, 3E)-Isopropyl 2-(2-bromo-3-methoxy-5-methylbenzylidene)-6-methylhepta-3,5-dienoate (10)

To a solution of bromo aldehyde $\mathbf{9}(2.22 \mathrm{~g}, 9.7 \mathrm{mmol})$ and phosphonoacetate 8 (3.43 g, 11.8 $\mathrm{mmol})$ in $120 \mathrm{~mL}$ THF and $6 \mathrm{~mL}$ of $\mathrm{H}_{2} \mathrm{O}, \mathrm{Ba}(\mathrm{OH})_{2}(7.35 \mathrm{~g}, 43 \mathrm{mmol})$ was added in portions with vigorous stirring at $40{ }^{\circ} \mathrm{C}$. After $10 \mathrm{~min}$, the reaction was allowed to reach $\mathrm{rt}$ and was diluted with $200 \mathrm{~mL} \mathrm{CH}_{2} \mathrm{Cl}_{2}$. It was washed with $1 \times 100 \mathrm{~mL}$ saturated $\mathrm{NaHCO}_{3}$ and $1 \times 100$ $\mathrm{mL}$ brine. It was dried with $\mathrm{MgSO} 4$, filtered through Celite and concentrated in vacuo. After flash chromatography (1\% TEA, $10 \%$ ethyl acetate in hexane), $3.2 \mathrm{~g} \mathrm{(84 \% )}$ of the brom oester was obtained as a viscous oil. IR (neat): 2974, 2930, 1714, 1234, $1096 \mathrm{~cm}^{-1} ;{ }^{1} \mathrm{H}$ NMR $\left(\mathrm{CDCl}_{3}, 300 \mathrm{MHz}\right) \delta 7.33(\mathrm{~s}, 1 \mathrm{H}), 7.16(\mathrm{dd}, 1 \mathrm{H}, \mathrm{J}=11.0,15.6), 6.79(\mathrm{~s}, 1 \mathrm{H}), 6.67(\mathrm{~s}, 1 \mathrm{H}), 6.22$ $(\mathrm{d}, 1 \mathrm{H}, \mathrm{J}=15.6 \mathrm{~Hz}), 5.82(\mathrm{~d}, 1 \mathrm{H}, \mathrm{J}=11.0 \mathrm{~Hz}), 5.22($ septet, $1 \mathrm{H}, \mathrm{d}=6.0 \mathrm{~Hz}), 3.90(\mathrm{~s}, 3 \mathrm{H}), 2.33$ $(\mathrm{s}, 3 \mathrm{H}), 1.79(\mathrm{~s}, 6 \mathrm{H}), 1.38(\mathrm{~s}, 3 \mathrm{H}), 1.36(\mathrm{~s}, 3 \mathrm{H}) ;{ }^{13} \mathrm{C} \mathrm{NMR}\left(\mathrm{CDCl}_{3}, 125 \mathrm{MHz}\right) \delta$ 167.0, 155.8, 138.3, 137.6, 137.4, 135.8, 132.2, 131.8, 126.2, 123.9, 122.2, 112.2, 110.1, 68.4, 56.2, 26.2, 21.8, 21.4, 18.6; HRMS calcd for $\mathrm{C}_{20} \mathrm{H}_{25} \mathrm{O}_{3} \mathrm{BrNa}[\mathrm{M}+\mathrm{Na}]^{+} 415.0879$; Found: 415.0875 .

\section{Isopropyl (2E,3E)-2-(2-\{[R-methylphenyl(oxido)- $\lambda^{6}$-sulfanylidene $]$ amino $\}$ benzylidene)-6- methylhepta-3,5-dienoate (12)}

A $100 \mathrm{~mL}$ round bottom flask with condenser was charged with palladium acetate $(15 \mathrm{mg}$, $0.065 \mathrm{mmol}$ ), rac-BINAP ( $60 \mathrm{mg}, 0.1 \mathrm{mmol}$ ), in $35 \mathrm{~mL}$ toluene. The mixture was stirred for $15 \mathrm{~min}$ at rt. The bromoester $10(510 \mathrm{mg}, 0.5 \mathrm{mmol})$ and $(R)-\mathbf{1 1}(220 \mathrm{mg}, 0.77 \mathrm{mmol})$ in $5 \mathrm{~mL}$ toluene was added, followed by addition of $\mathrm{Cs}_{2} \mathrm{CO}_{3}(1.17 \mathrm{~g}, 2 \mathrm{mmol})$. It was refluxed at 110 ${ }^{\circ} \mathrm{C}$ for $12 \mathrm{~h}$. Then it was diluted with $40 \mathrm{~mL} \mathrm{CH}_{2} \mathrm{Cl}_{2}$, filtered through Celite, which was washed with $3 \times 50 \mathrm{~mL} \mathrm{CH}_{2} \mathrm{Cl}_{2}$, and concentrated in vacuo. After flash chromatography (25\% ethyl acetate in hexanes), $491 \mathrm{mg}$ ( $81 \%$ ) of $\mathbf{1 2}$ was obtained as pale yellow semisolid. IR (film): 3064, 2974, 2925, 1703, 1560, 1454, 1336, 1270, 1233, 1094, $735 \mathrm{~cm}^{-1} ;{ }^{1} \mathrm{H}$ NMR $\left(\mathrm{CDCl}_{3}\right.$, $500 \mathrm{MHz}) \delta 8.00(\mathrm{dd}, 2 \mathrm{H}, \mathrm{J}=1.5,10.0 \mathrm{~Hz}), 7.77(\mathrm{~s}, 1 \mathrm{H}), 7.56-7.50(\mathrm{~m}, 3 \mathrm{H}), 7.20(\mathrm{dd}, 1 \mathrm{H}, \mathrm{J}$ $=11.0,15.5 \mathrm{~Hz}), 6.80(\mathrm{~s}, 1 \mathrm{H}), 6.60(\mathrm{~s}, 1 \mathrm{H}), 6.40(\mathrm{~d}, 1 \mathrm{H}, \mathrm{J}=15.5 \mathrm{~Hz}), 5.87(\mathrm{~d}, 1 \mathrm{H}, \mathrm{J}=11.0$ $\mathrm{Hz}), 5.21(\mathrm{~m}, 1 \mathrm{H}, \mathrm{J}=6.0 \mathrm{~Hz}), 3.59(\mathrm{~s}, 3 \mathrm{H}), 3.10(\mathrm{~s}, 3 \mathrm{H}), 2.28(\mathrm{~s}, 3 \mathrm{H}), 1.81(\mathrm{~s}, 6 \mathrm{H}), 1.36(\mathrm{~s}$, $3 \mathrm{H}), 1.34(\mathrm{~s}, 3 \mathrm{H}) ;{ }^{13} \mathrm{C} \mathrm{NMR}(\mathrm{CDCl} 3,125 \mathrm{MHz}) \delta 167.6,152.2,142.4,137.2,136.9,132.3$, 132.0, 131.6, 130.7, 130.2, 129.8, 128.9, 127.5, 126.6, 123.4, 113.1, 67.8, 55.6, 46.0, 26.2, 22.0, 21.2, 18.6; HRMS calcd for $\mathrm{C}_{27} \mathrm{H}_{33} \mathrm{NO}_{4} \mathrm{SNa}[\mathrm{M}+\mathrm{Na}]^{+}$490.2022; Found: 490.2016; $[\alpha]^{25} \mathrm{D}=77.975\left(\mathrm{c} 0.79, \mathrm{CHCl}_{3}\right)$. 


\section{Isopropyl (2S,3E)-6-methyl-2-[(2R. 4R)-2-methyl-2-oxido-3,4-dihydro-2 $\lambda^{4}, 1$-benzothiazin-4- yl]hepta-3,5-dienoate (13)}

A $100 \mathrm{~mL}$ round-bottom flask was charged with bromo ester $(1.58 \mathrm{~g}, 3.38 \mathrm{mmol})$ in $40 \mathrm{~mL}$ THF. LiHMDS $6 \mathrm{~mL}(1 \mathrm{M}$ in toluene, $6 \mathrm{mmol})$ was added dropwise to it at $-78{ }^{\circ} \mathrm{C}$. After 10 min at $-78{ }^{\circ} \mathrm{C}$, the reaction was quenched with $1 \mathrm{~N} \mathrm{HCl}$ in methanol at $-78-^{\circ} \mathrm{C}$. It was poured into water, extracted with $3 \times 20 \mathrm{~mL} \mathrm{CH}_{2} \mathrm{Cl}_{2}$, dried with $\mathrm{MgSO}_{4}$, and concentrated in vacuo. After flash chromatography (30\% ethyl acetate in hexanes), $1.28 \mathrm{~g} \mathrm{(81 \% )} \mathrm{of} \mathbf{1 3}$ was obtained as the main isomer. IR (film): 2970, 2921, 2868, 1720, 1462, 1245, $1102 \mathrm{~cm}^{-1} ;{ }^{1} \mathrm{H}$ NMR $\left(\mathrm{CDCl}_{3}, 500 \mathrm{MHz}\right) \delta 8.10-8.12(\mathrm{~m}, 2 \mathrm{H}), 7.62-7.66(\mathrm{~m}, 1 \mathrm{H}), 7.54-7.57(\mathrm{~m}, 2 \mathrm{H}), 6.68(\mathrm{~s}, 1 \mathrm{H})$, $6.64(\mathrm{~s}, 1 \mathrm{H}), 6.26(\mathrm{dd}, 1 \mathrm{H}, \mathrm{J}=11.0,15.0 \mathrm{~Hz}), 5.77(\mathrm{~d}, 1 \mathrm{H}, \mathrm{J}=11.0 \mathrm{~Hz}), 5.49(\mathrm{dd}, 1 \mathrm{H}, \mathrm{J}=7.5$, $15.0 \mathrm{~Hz}$ ), 4.89 (septet, $1 \mathrm{H}, \mathrm{J}=6.0 \mathrm{~Hz}), 3.96(\mathrm{t}, 1 \mathrm{H}, \mathrm{J}=7.0 \mathrm{~Hz}), 3.88(\mathrm{~s}, 3 \mathrm{H}), 3.60-3.64(\mathrm{~m}$, $1 \mathrm{H}), 3.52-3.56(\mathrm{~m}, 2 \mathrm{H}), 2.30(\mathrm{~s}, 3 \mathrm{H}), 1.75(\mathrm{~s}, 3 \mathrm{H}), 1.69(\mathrm{~s}, 3 \mathrm{H}), 1.15(\mathrm{~d}, 3 \mathrm{H}, \mathrm{J}=6.5 \mathrm{~Hz}), 1.05$ $(\mathrm{d}, 3 \mathrm{H}, \mathrm{J}=6.0 \mathrm{~Hz}) ;{ }^{13} \mathrm{C} \mathrm{NMR}\left(\mathrm{CDCl}_{3}, 125 \mathrm{MHz}\right) \delta 172.3,152.6,139.4,136.8,133.8,132.1$, $131.1,129.9,129.5,129.4,124.9,124.9,124.3,119.4,111.9,68.4,56.2,51.1,49.2,38.4,26.2$, 21.8, 21.6, 18.6; HRMS calcd for $\mathrm{C}_{27} \mathrm{H}_{33} \mathrm{NO}_{4} \mathrm{SNa}[\mathrm{M}+\mathrm{Na}]^{+}$490.2022; Found: 490.2012; $[\alpha]^{25} \mathrm{D}=-60.48\left(\mathrm{c} 1.66, \mathrm{CHCl}_{3}\right)$.

\section{(2 R,4R)-,4-[(1S,2E)-1,5-Dimethyl-2,4-hexadienyl]-3,4-dihydro-8-methoxy-6-methyl -2- phenyl-2y4-2,1-benzothiazine-2-oxide (4)}

To a solution of mesylate $15(71 \mathrm{mg}, 0.15 \mathrm{mmol})$ and LiI (201 $\mathrm{mg}, 1.5 \mathrm{mmol})$ in $7.5 \mathrm{~mL}$ dry THF at $-30^{\circ} \mathrm{C}$, was added $1.5 \mathrm{~mL}$ of $1 \mathrm{M} \mathrm{LiBHEt}_{3}$ in THF slowly. After it was kept at $-30^{\circ}$ $\mathrm{C}$ for $26 \mathrm{~h}$, it was diluted with $15 \mathrm{~mL} \mathrm{DCM}$ and quenched with $10 \mathrm{~mL} 10 \% \mathrm{NaOH}$, and $5 \mathrm{~mL}$ $30 \% \mathrm{H}_{2} \mathrm{O}_{2}$. After it was stirred for $30 \mathrm{~min}$ at $\mathrm{rt}$, it was washed with $10 \mathrm{~mL}$ saturated $\mathrm{Na}_{2} \mathrm{~S}_{2} \mathrm{O}_{3}$ solution, followed by $30 \mathrm{~mL}$ brine. After drying with $\mathrm{Na}_{2} \mathrm{SO}_{4}$, it was concentrated under vacuum. Chromatography (20\% ethyl acetate in hexanes) afforded $45 \mathrm{mg}(79 \%)$ of 4 as a colorless oil. The NMR data matched the published data. ${ }^{4}$

\section{Supplementary Material}

Refer to Web version on PubMed Central for supplementary material.

\section{Acknowledgments}

This work was supported by the NIH (1R01-AI59000-01A1) to whom we are grateful.

SUPPORTING INFORMATION Characterization data for compound $\mathbf{1 6}$ and copies of proton and carbon spectra for previously unreported compounds. This material is available free of charge via the Internet at http://pubs.acs.org.

\section{References}

1. See: (a) Mitscher LA, Baker W. Med Res Rev 1998;18:363-374. [PubMed: 9828037] (b) Friedman, LN., editor. Tuberculosis: Current Concepts and Treatment. CRC; Boca Raton, FL: 2001. (c) Kaufmann, SHE.; Rubin, E., editors. Handbook of tuberculosis; molecular biology and biochemistry. Wiley-VCH; Weinheim: 2008. (d) Kaufmann, SHE.; Britton, WJ., editors. Handbook of tuberculosis; immunology and cell biology. Wiley-VCH; Weinheim: 2008. (e) Kaufmann, SHE.; van Helden, P., editors. Handbook of tuberculosis; clinics, diagnostics, therapy and epidemiology. Wiley-VCH; Weinheim: 2008.

2. Gutierrez-Lugo MT, Bewley CAJ. Med Chem 2008;51:2606-2612. (b) Copp BR, Pearce AN. Nat Prod Rep 2007;24:278-297. [PubMed: 17389998]

3. Rodriguez AD, Ramirez C, Rodriguez II, Gonzalez E. Org Lett 1999;1:527-530. [PubMed: 10822593]

4. (a) Johnson TW, Corey EJ. J Am Chem Soc 2001;123:4475-4479. [PubMed: 11457233] (b) Davidson JP, Corey EJ. J Am Chem Soc 2003;125:13486-13489. [PubMed: 14583045] 
5. (a) Harmata M, Hong X. Org Lett 2004;6:2201-2203. [PubMed: 15200320] (b) Harmata M, Hong X. Org Lett 2005;7:3583-3583.

6. Minami T, Tokumasu S, Mimasu R, Hirao I. Chem Lett 1985:1099-1102.

7. Koyama H, Kamikawa T. J Chem Soc Perkin Trans 1 1998;1:203-209.

8. Nicolaou KC, Nold AL, Milburn RR, Schindler CS, Cole KP, Yamaguchi J. J Am Chem Soc 2007;129:1760-1780. [PubMed: 17249678]

9. (a) Harmata M, Pavri N. Angew Chem, Int Ed 1999;38:2419-2422. (b) Bolm C, Hildebrand JP. Tetrahedron Lett 1998;39:5731-5734. (c) Bolm C, Hildebrand JP. J Org Chem 2000;65:169-175. [PubMed: 10813912]

10. Only trace amounts of a compound assigned as an intramolecular Heck reaction product were isolated whenever this reaction was performed. This product 16 was characterized and details on it are reported in the supporting information. The enantiopurity of 12 is considered to be the same as that of $(R)-11$, which was established by both optical rotation and HPLC to be $100 \%$, within experimental error.

11. Harmata M, Hong X. J Am Chem Soc 2003;125:5754-5756. [PubMed: 12733915]

12. Diastereomeric ratios were determined based on proton NMR analysis of crude reaction mixtures. The diastereoselectivity varied from 7-10:1. The minor isomer was not characterized but could be separated from the desired diastereomer by column chromatography. 
<smiles>CCOC(=O)C(C)=Cc1cc(C)cc(OC)c1N=[Sb](C)(=Nc1ccccc1)OC</smiles><smiles>COc1cc(C)cc2c1N=[S+]([O-])(c1ccccc1)C[C@H]2C(C)/C=C/C=C(C)C</smiles>

SCHEME 1.

Summary of our first synthesis of pseudopteroxazole 

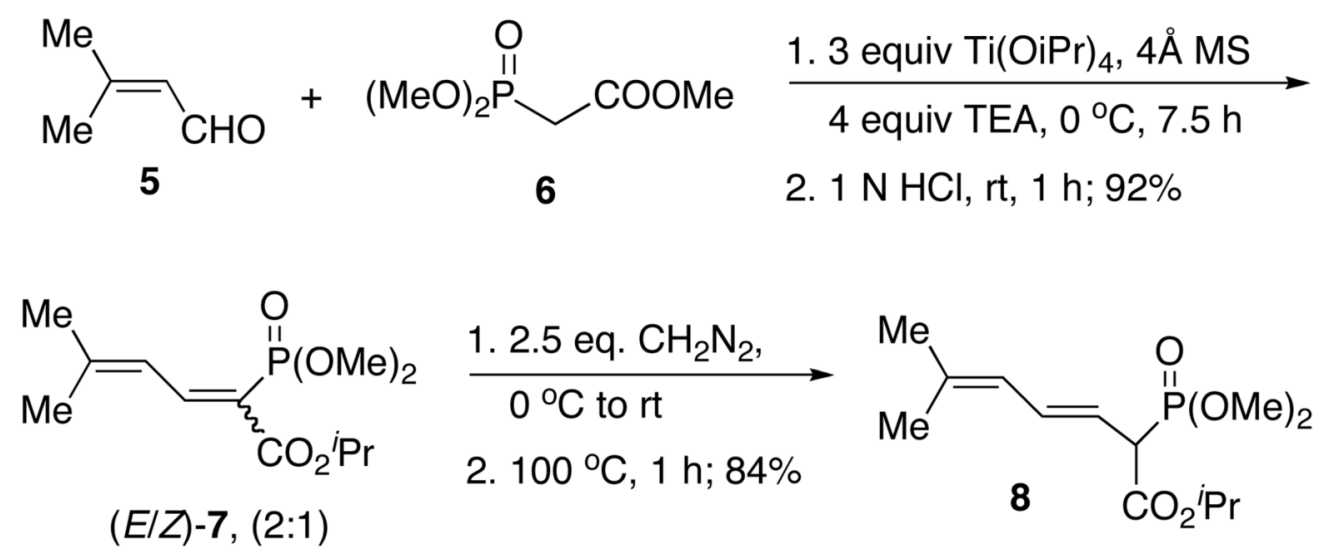

Scheme 2.

Preparation of Phosphonate 8 
<smiles>COc1cc(C)cc(C=O)c1Br</smiles>

9<smiles>COc1cc(C)cc(/C=C(\C=C\C=C(C)C)C(=O)OC(C)C)c1Br</smiles>

10

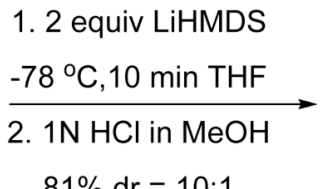

$81 \% \mathrm{dr}=10: 1$<smiles>CCOC(=O)C(=CC=C(C)C)[PH](=O)OC</smiles>

8 $\underset{\text { THF: } \mathrm{H}_{2} \mathrm{O}=20: 1}{\stackrel{4.4 \text { equiv } \mathrm{Ba}(\mathrm{OH})_{2}}{\longrightarrow}}$
$40^{\circ} \mathrm{C}, 10 \mathrm{~min}, 84 \%$

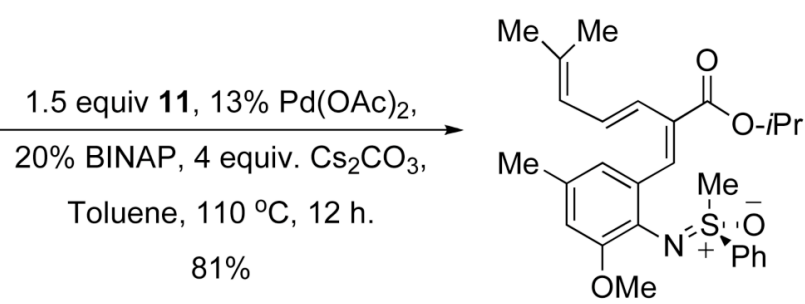

12<smiles>COc1cc(C)cc2c1N=[S+]([O-])c1ccccc1C2[C@H](/C=C/C=C(C)C)C(=O)OC(C)C</smiles>

13<smiles>COc1cc(C)cc2c1N=[P+]([O-])[C-]C2[C@H](/C=C/C=C(C)C)CO</smiles>

1.5 equiv $\mathrm{MsCl}, 2$ equiv TEA

DCM, $0^{\circ} \mathrm{C}$ to rt, $17 \mathrm{~h}$

$79 \%$

14<smiles>COc1cc(C)cc2c1N=[Sb]([O-])([O-])CC2C(C)C=CC=C(C)C</smiles>

10 equiv DIBAL THF, $0{ }^{\circ} \mathrm{C}, 2 \mathrm{~h}$ $88 \%$<smiles>CC[C@H](/C=C/C=C(C)C)C1C[N+]([O-])=Cc2c(OC)cc(C)cc21</smiles>

15

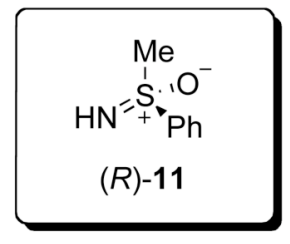

Scheme 3.

Formal Synthesis of Pseudopteroxazole 